Jurnal Ilmu dan Teknologi Kesehatan

Vol 8, No 1, September 2020,

ISSN: 2338-9095 (Print)

ISSN: 2338-9109 (online)

\title{
Ethanol and Methanol Levels in The Oplosan Liquor
}

\author{
Angki Purwanti, Ni Putu Aryadnyani \\ Poltekkes Kemenkes Jakarta III, Indonesia \\ Email: angki.purwanti.110564@gmail.com
}

\author{
Article history \\ Posted, June 21st, 2020 \\ Reviewed, Sept 10th, 2020 \\ Received, Sept 27th, 2020
}

\begin{abstract}
Oplosan liquor is one form of illegal drink that is often found in police raids in various areas. The purpose of this study was to determine the ethanol and methanol levels in mixed liquor obtained from the results of the Sector Police raids in Cipayung District, East Jakarta, in 2017. This study was a cross-sectional descriptive study. Determination of ethanol and methanol levels is done by gas chromatography at the Daerah Khusus Ibukota Jakarta Health Laboratory. The sample in this study amounted to 14 samples. Based on the research obtained Ethanol content from test material $(10.08-50.14) \% \mathrm{v} / \mathrm{v}$ with an average $(28,39 \pm 15,09) \% \mathrm{v} / \mathrm{v}$ and methanol content is $(0.08-2.04) \% v / v$ with an average of $(0,81 \pm 0,72) \% \mathrm{v} / \mathrm{v}$. Samples whose ethanol content is equivalent to alcoholic groups $A, B$, and $C$ are $0 \%$, six bottles (42.86\%), and eight bottles (51.13\%). All samples contained methanol with levels $>0.01 \%$ and were not packaged according to the requirements of the Regulation of the Indonesian Food and Drug Supervisory Agency No. 14/2016 (BPOM). It is suggested to do a follow-up in counseling related to mixed alcohol, especially for adolescents in this area. Further research is suggested to identify illegal drugs in the confiscated alcoholic drinks from this area. It is recommended to the Cipayung District Police to clean the area from mixed alcohol.
\end{abstract}

Keywords: mixed liquor; ethanol levels; methanol levels

\begin{abstract}
ABSTRAK
Minuman keras oplosan adalah salah satu bentuk minuman ilegal yang sering ditemukan pada razia polisi di berbagai daerah. Minuman ini banyak menyebabkan kematian dan keracunan berupa kebutaan akibat toksisitas dari metanol. Tujuan dari penelitian ini adalah untuk menentukan kadar etanol dan metanol dalam minuman keras oplosan yang diperoleh dari hasil razia Kepolisian Sektor di Kecamatan Cipayung, Jakarta Timur pada tahun 2017. Penelitian ini adalah penelitian deskriptif secara potong lintang. Penentuan kadar etanol dan metanol dilakukan dengan kromatografi gas di Laboratorium Kesehatan Daerah Khusus Ibukota Jakarta. Sampel dalam penelitian ini berjumlah 14 sampel. Berdasarkan penelitian diperoleh kandungan Etanol dari bahan uji (10.08-50.14)\% v/v dengan rata-rata $(28,39 \pm 15,09) \% \mathrm{v} / \mathrm{v}$ dan kandungan metanol adalah $(0.08-2.04) \% \mathrm{v} / \mathrm{v}$ dengan rata-rata $(0,81 \pm 0,72) \% \mathrm{v} / \mathrm{v}$. Sampel yang kadar etanolnya setara dengan miras golongan A, B dan C adalah $0 \%, 6$ botol $(42,86 \%)$ dan 8 botol $(51,13 \%)$. Seluruh sampel mengandung metanol dengan kadar $>0,01 \%$ serta tidak dikemas sesuai persyaratan Peraturan Badan Pengawas Obat dan Makanan RI No.14 Tahun 2016 (BPOM). Disarankan untuk melakukan tindak lanjut berupa penyuluhan terkait miras oplosan khususnya pada remaja
\end{abstract}


di wilayah ini. Penelitian selanjutnya disarankan melakukan identifikasi obat-obat terlarang dalam miras oplosan hasil sitaan dari wilayah ini serta disarankan pada Polsek Kecamatan Cipayung untuk membersihkan wilayah dari miras oplosan.

Kata Kunci: minuman keras oplosan; kadar etanol; kadar metanol

\section{INTRODUCTION}

Alcoholic drinks are also called liquor or "miras" containing ethanol $\left(\mathrm{C}_{2} \mathrm{H}_{5} \mathrm{OH}\right)$. This drink is processed from carbohydrates by fermentation and distillation or fermentation without distillation. The ethanol content is known as group A liquor with ethanol content up to $5 \%$, group $\mathrm{B}$ with ethanol (5-20)\%, and group $\mathrm{C}$ above $20 \%$ to $55 \%$ (Per.Ka.BPOM No.14 Tahun 2016). Alcoholic drinks, according to the dose, are beneficial for health. A glass of wine per day can increase estrogen levels in women to slow bone damage, and men can reduce the occurrence of prostate cancer. One and a half beers per day can increase insulin sensitivity, reduce the risk of diabetes, kidney stones, and protect the brain from Alzheimer's. Vodka applied to the skin can shrink facial skin pores, and when applied to the scalp, it can reduce dandruff (Polihu, 2017).

Alcohol consumption of more than 30 grams per day can increase the production of triglycerides in the liver. This excess production will be released into the blood vessels resulting in the accumulation of triglycerides in the blood vessels, increasing the risk of coronary heart disease (Purbayanti, Nur,2017). The long-term effect of alcohol consumption can increase cortisol in the blood so that the reninangiotensin-aldosterone system's activity increases, which also affects the increase in blood pressure (Jayanti, Wiradnyani, Ariyasa, 2017). Ethanol compounds in alcohol will damage the gastric mucosa by increasing reactive oxygen species. Direct gastric contact with alcohol can cause metabolic and functional changes in the gastric mucosa, resulting in diseases such as ulcers and peptic ulcers. Changes in the gastric mucosa due to alcohol consumption can disrupt the digestion of nutrients associated with malnutrition and weight loss (Pratama, Muhartono, 2019). In addition to causing physical health problems, the use of alcohol also causes psychological disorders in the form of irregularities of thought patterns that lead to violent and criminal behavior that endangers oneself and others. These drinks can cause addiction and tolerance, lead to violent behavior and increase traffic accidents due to driving in a state of alcohol intoxication, so drinking alcohol 
should be reduced or even stopped (Tritama,2015). Indonesia's crucial issue is an "oplosan" liquor, which is usually sold illegally, cheap and only packaged in plastic bags without labels, easy to obtain, especially in herbal medicine stalls (Muliadi, 2019). Gerakan Nasional Antimiras, from 2011 to 2016, recorded the number of victims who died due to oplosan liquor reaching 18,000 people (Yanti, Arisma, 2019). In 2018 (Jan - April), this drink has killed 144 people (Muliadi,2019).

An "oplosan" liquor is a type of alcoholic drink such as vodka, red wine, white wine, or beer mixed with soft drinks, milk, energy-enhancing drinks, and herbal medicines (Mumpuni,2016). A solution that is often added to "oplosan" liquor drinks is methanol, a component of methylated spirits. This solvent is commonly used for industrial purposes, is toxic and not for consumption. Methanol is physically similar to ethanol, mixes well with water but has higher intoxication and toxicity than ethanol. Oplosan contains other additional ingredients whose types and levels are unknown (Muliadi,2019). In "oplosan" liquor levels of methanol can reach (40-60)\%, whereas $30 \mathrm{ml}$ of methanol can damage the eye nerves and $100 \mathrm{ml}$ of methanol causes death (Mumpuni, 2016). It is alleged that there are types of drugs such as Dextro, lexotan, and several types of illegal drugs consumed with this "oplosan" (Belvage,2017). The results of the forensic laboratory examination of the Semarang branch found that the mixed liquor circulated in the area contained $18.16 \%$ ethanol and $0.01 \%$ methanol (Yanti, Arisma, 2019). Post mortem examination of victims of "oplosan" liquor showed enlargement of the liver sinusoids. It is because the liver is the leading metabolic site of methanol. The victim also found dilated blood vessels in the kidneys, cerebellum, heart, and stomach. There are signs of irritation and inflammation in the gastric mucosa due to decreased $\mathrm{pH}$ because of the entry of methanol and ethanol from the consumed oplosan liquor (Hamidah, 2017). Methanol is metabolized in the liver by the alcohol dehydrogenase enzyme to form formaldehyde, which will be metabolized by the aldehyde dehydrogenase enzyme to form formic acid. Both of these metabolites are toxic to the body, especially formic acid, causing metabolic acidosis and permanent blindness. Symptoms of methanol poisoning appear 30 minutes to 2 hours after the ingestion of "oplosan". Signs of poisoning include nausea, vomiting, drowsiness, vertigo, motion sickness, gastritis, and diarrhea (Mumpuni, 2016). 
Methanol poisoning damages the eye nerves causing a decrease in vision to the blind. Hidayati's research stated that in Cipto Mangunkusumo Hospital, there were 24 optic neuropathy cases caused by methanol in 2002-2006. Triningrat states that there are 31 cases of optic neuropathy in RSCM due to methanol during 2013 and 2014. The increase in cases can be caused by alcohol adulteration circulating freely in the community (Yunard, Nusanti, and Sidik, 2016). Cases of methanol poisoning that occurred from June 2009 to May 2010 in Sanglah Hospital were $18 \%$ with 76 cases, and constitute $18 \%$ of all cases of poisoning in Sanglah Hospital (Triningrat, Rahayu, and Manuaba, 2010).

Cipayung Subdistrict East Jakarta is a fostered area of Jakarta Poltekkes III, with 2,736 $\mathrm{Km}^{2}$. In the Cipayung sub-district, there were still sales of "oplosan" liquor. In the month of Ramadhan in 2016, the East Jakarta Cipayung Police inspected six grocery stalls in Ceger, Bambu Apus, Setu, and Lubang Buaya villages. The alcohol was immediately destroyed, including "oplosan" liquor, without checking its ethanol and methanol levels. The author wants to know the ethanol and methanol levels of the "oplosan" liquor circulating in the Cipayung sub-district.

\section{METHOD}

This research is a descriptive-analytic study with a cross-sectional design. The research sample in the form of "oplosan" liquor was obtained from Cipayung Sector Police in East Jakarta, which resulted from confiscation during a Ramadhan month in 2017. Samples in the form of oplosan liquor as many as 14 from different places in the District Cipayung. Each sample is taken $200 \mathrm{ml}$ and transferred into small, clean, dry, and covered bottles. Analysis of ethanol and methanol levels in the sample was carried out in DKI LABKESDA by gas chromatography. This study was approved by the Health Research Ethics Commission of the Jakarta Health Polytechnic III. Ethics Approval Number: KEPK-PKKJ3 / 009 / IV / 2017.

\section{RESULTS AND DISCUSSION}

The color of the sample varies from colorless, light yellow, yellow-brown, brown to dark brown. All clear samples had no turbidity and no insoluble particles. The entire sample smelled typical of ethanol, there was a weak smell, but most of it smelled strong. Determination of the ethanol content contained in the sample by gas chromatography and obtained the following results. 
Table 1. Ethanol and Methanol Levels in Oplosan Miras From the Cipayung District Region in 2017

\begin{tabular}{cccc}
\hline Level $(\% \mathbf{v} / \mathbf{v})$ & minimum & maximum & mean \\
\hline ethanol & 10,08 & 50,04 & $28 \pm 15,09$ \\
methanol & 0,08 & 2,04 & $0,81 \pm 0,72$ \\
\hline
\end{tabular}

The lowest ethanol content was $10.08 \%$ $\mathrm{v} / \mathrm{v}$, and the highest ethanol content was $50.14 \% \mathrm{v} / \mathrm{v}$, the mean ethanol content was $(28.39 \pm 15.09) \% \mathrm{v} / \mathrm{v}$. The lowest methanol content was $0.08 \% \mathrm{v} / \mathrm{v}$, and the highest methanol content was $2.04 \% \mathrm{v} / \mathrm{v}$. The mean methanol content was $(0.81 \pm 0.72) \% \mathrm{v} / \mathrm{v}$. Of the 14 bottles of alcohol for the test material, based on the ethanol content, there were six bottles $(42.86 \%)$ equivalent to group B liquor, and there were eight bottles $(57.14 \%)$ equivalent to group C liquor. No equivalent was found with group
A. All test liquor contains methanol > $0.01 \%$. The oplosan liquor found in the study area was circulated without a label stating its alcohol content. Both of these things violate the Regulation of Head of the Republic of Indonesia BPOM No. 14/2016. The Cipayung Police found "oplosan" liquor in herbal stalls and stalls around Cipayung District, East Jakarta, which according to the Regulation of the Minister of Trade of the Republic of Indonesia No: 15 / M-DAG / PER / 3/2006, is not a place to sell alcoholic drinks.

Table 2. Comparison of Ethanol Levels in Mixed Alcohol in this Study

With Previous Research

\begin{tabular}{|c|c|c|c|c|}
\hline No. & Place and Year & $\begin{array}{l}\text { Number of } \\
\text { Samples }\end{array}$ & Ethanol Levels & $\begin{array}{l}\text { Alcoholic } \\
\text { beverage } \\
\text { group }\end{array}$ \\
\hline 1 & $\begin{array}{l}\text { Cipayung District, East } \\
\text { Jakarta } \\
2017\end{array}$ & 14 & $\begin{array}{l}(10,08-50,14) \% \mathrm{v} / \mathrm{v} \\
\text { average } \\
28,39 \% \mathrm{v} / \mathrm{v}\end{array}$ & $\begin{array}{l}\mathrm{A}=0 \% \\
\mathrm{~B}=43 \% \\
\mathrm{C}=57 \%\end{array}$ \\
\hline 2 & $\begin{array}{l}\text { Jatinegara District } \\
\text { East Jakarta } \\
2017 \text { (Ramdhania, 2017) }\end{array}$ & 10 & $\begin{array}{l}(3,10-11,76) \% \mathrm{v} / \mathrm{v} \\
\text { average } \\
8,49 \% \mathrm{v} / \mathrm{v}\end{array}$ & $\begin{array}{l}\mathrm{A}=20 \% \\
\mathrm{~B}=80 \% \\
\mathrm{C}=0 \%\end{array}$ \\
\hline 3 & $\begin{array}{l}\text { Kramat Jati District, East } \\
\text { Jakarta } \\
2017 \text { (Habibah, 2017) }\end{array}$ & 10 & $\begin{array}{l}(2,53-12,25) \% \mathrm{v} / \mathrm{v} \\
\text { average } \\
7,77 \%\end{array}$ & $\begin{array}{l}A=80 \% \\
B=20 \% \\
C=0 \%\end{array}$ \\
\hline 4 & $\begin{array}{l}\text { Kramat Jati District, East } \\
\text { Jakarta } \\
\text { Year } 2013 \text { (Syarifudin, } \\
\text { 2013) }\end{array}$ & 10 & $\begin{array}{l}(10,40-28,70) \% \mathrm{v} / \mathrm{v} \\
\text { average } \\
19,76 \% \mathrm{v} / \mathrm{v}\end{array}$ & $\begin{array}{l}A=0 \% \\
B=60 \% \\
C=40 \%\end{array}$ \\
\hline 5 & $\begin{array}{l}\text { Kragan Rembang District, } \\
\text { Central Java } \\
\text { In } 2016 \text { (Suwanti, no date) }\end{array}$ & 6 & $\begin{array}{l}(16,52-36,95) \% \mathrm{v} / \mathrm{v} \\
\text { average } \\
26,58 \% \mathrm{v} / \mathrm{v} .\end{array}$ & $\begin{array}{l}\mathrm{A}=16,67 \% \\
\mathrm{~B}=66,67 \% \\
\mathrm{C}=16,67 \%\end{array}$ \\
\hline
\end{tabular}


Ethanol levels of oplosan liquor obtained from the Cipayung subdistrict area of East Jakarta were highest compared to the results of previous similar studies. According to the head of the criminal unit of the Cipayung Police, the Cipayung area of East Jakarta is not an area prone to alcohol because, in this area, there is no localization. Unlike the Pulo Gadung, Kramat Jati, and Jatinegara areas, alcohol is one of the primary community diseases and is closely related to prostitution. However, from this study, it can be seen that the alcoholic liquor circulating in this area contains higher levels of ethanol and methanol than the mixed alcohol obtained from Jatinegara, Kramat Jati, and Kragan Districts, Rembang, Central Java, so it is more dangerous if consumed. It was also higher than the ethanol content in "oplosan" alcohol that had been examined by the Semarang Branch Forensic Laboratory, namely $18.16 \%$.

Table 3. Comparison of Methanol Levels in Oplosan Liquor in This Research with Previous Research

\begin{tabular}{|c|c|c|c|c|}
\hline No. & Place and Year & $\begin{array}{c}\text { Number } \\
\text { of } \\
\text { Samples }\end{array}$ & Methanol Levels & Information \\
\hline 1 & $\begin{array}{l}\text { Cipayung District, } \\
\text { East Jakarta } \\
2017\end{array}$ & 14 & $\begin{array}{l}(10,08-50,14) \% \mathrm{v} / \mathrm{v} \\
\text { average } \\
28,39 \% \mathrm{v} / \mathrm{v}\end{array}$ & $\begin{array}{l}\text { All samples violated the } \\
\text { Regulation of Ka.BPOM RI } \\
\text { No. } 14 / 2016 \\
\text { Methanol content }>0.01 \%\end{array}$ \\
\hline 2 & $\begin{array}{l}\text { Kramat Jati District, } \\
\text { East Jakarta } \\
\text { The year } 2013 \\
\text { (Syarifudin, 2013) }\end{array}$ & 10 & $\begin{array}{l}(10,40-28,70) \% \mathrm{v} / \mathrm{v} \\
\text { average } \\
19,76 \% \mathrm{v} / \mathrm{v}\end{array}$ & $\begin{array}{l}\text { All samples violated the } \\
\text { Regulation of Ka.BPOM RI } \\
\text { No. } 14 / 2016 \\
\text { Methanol content }>0.01 \%\end{array}$ \\
\hline
\end{tabular}

The methanol concentration of mixed liquor from the Cipayung Sub-district area of East Jakarta was entirely above $0.01 \%$ $\mathrm{v} / \mathrm{v}$. The same as the mixed liquor research obtained from the District of Kramat Jati, East Jakarta. The average concentration of methanol in mixed liquor from Cipayung is 13 times higher than the average level of mixed liquor from Kramat Jati. This study shows that the level of methanol is directly proportional to the level of ethanol in "oplosan" liquor. The higher the ethanol content, the higher the methanol content, the correlation coefficient between the methanol and ethanol levels from this experiment is $r=0.67$. It shows that there is a strong correlation. It is estimated that "oplosan" liquor samples are mixed with 
"spiritus", which are chemical liquids whose main composition is technical ethanol mixed with pyridine, denatonium, and methanol to about 10\% (Wikipedia, 2017).

Spiritus is widely used to "oplosan" liquor because its methanol content has a more significant effect than ethanol; the price of "spiritus" is relatively low and easily obtained. Pure ethanol and alcoholic drinks are heavily taxed on sales. To ease the tax burden on its use, most sellers mix ethanol with methanol. The mixture of ethanol and methanol, when consumed, has a worse impact on health when compared to ethanol consumption alone. Both of these compounds, when taken together, have a terrible synergistic effect on liver cell damage that has been proven through experiments using Wistar Rats (Nabila, 2011).

In Indonesia, it is permissible to have methanol in alcoholic drinks with a maximum level of $0.01 \% \mathrm{v} / \mathrm{v}$, while in other countries varying as in Brazil, it is permitted to $0.5 \%$, in Thailand to $0.024 \%$ in the USA (FDA) to $0.1 \%$ and in Nigeria up to $0,0005 \%$. Methanol is produced during the fermentation process of tubers/fruit whose main product is ethanol. Bulbs/fruit as a raw material in liquor manufacture brewed with yeast Saccharomyces cerevisiae for some time. The purer the Saccharomyces cerevisiae variety used, the smaller the methanol content formed. Suppose the yeast of Saccharomyces cerevisiae used is not pure. In that case, there is a specific microbial mixture or the presence of certain varieties of Saccharomyces cerevisiae, which can activate the enzyme pectin methylesterase (PEM). The enzyme will convert the methoxy group on pectin to methanol (Ohimain, 2016).

\section{CONCLUSION}

Ethanol levels of oplosan liquor obtained from the Cipayung subdistrict area of East Jakarta were highest compared to the results of previous similar studies. All samples contained methanol with levels> $0.01 \%$ and were not packaged according to the requirements of the Regulation of the Indonesian Food and Drug Supervisory Agency No. 14/2016 (BPOM). Based on its methanol content, all of these mixed alcoholic drinks violate the provisions of BPOM RI No. 14 of 2016, which requires methanol levels $<0.01 \%$.

Counseling about the dangers of mixed alcohol needs to be done in schools in this area. The East Jakarta Police are advised to map the place where oplosan liquor is sold so that it is easy to clean the area from the 
circulation of mixed alcohol. For further research, it is recommended to examine the drugs contained in "oplosan" liquor.

\section{ACKNOWLEDGEMENT}

Authors would like to thank all parties involved in this study: Director of Poltekkes Kemenkes Jakarta III as the funder, Ethics Commission for Health Polytechnic of the Ministry of Health, Jakarta III, and Head of the Criminal Unit of the East Jakarta Cipayung Police who have provided samples in this study.

\section{REFERENCE}

Habibah, V. 2017. Penetapan Kadar Etanol dan Metanol pada Minuman Keras Oplosan di Wilayah Kramat Jati Tahun 2017. Karya Tulis Ilmiah. Jakarta: Poltekkes Kemenkes Jakarta III.

Hamidah, M.,Yulianti, K. 2017. Temuan Post Mortem Akibat Keracunan Metanol. E-Jurnal Medika, 6(7): 17.

Jayanti, I.G.A.N, Wiradnyani, N.K, Ariyasa, I.G. 2017. Pola Hubungan Konsumsi Minuman Beralkohol Terhadap Kejadian Hipertensi Pada Tenaga Kerja Pariwisata di Kelurahan Legian. The Indonesian Journal of Nutrition, 6 (1): 65-70.

BPOM RI. 2016. Peraturan Kepala Badan Pengawasan Obat dan Makanan Republik Indonesia No.4 Tahun 2016 Tentang Standar Keamanan Dan Mutu Minuman Beralkohol.
Perdagangan Republik Indonesia Tentang Pengawasan dan Pengendalian Impor, Pengedaran dan Penjualan, dan Perijinan Minuman Beralkohol. Indonesia.

Muliadi. 2019. Penanggulangan Peredaran Minuman Keras Oplosan (Studi Kasus di Kecamatan Sirenja Kabupaten Donggala. Maleo Law Jurnal, 3(2):123-141.

Mumpuni, R. Y. 2016. Tata Laksana Keracunan Minuman Keras Oplosan (Methanol dan Ethylene Glycol) dengan Fomepizole, Etanol, dan Hemodialisis. Journal of Nursing Care \& Biomolecular, 1(1): 1-8.

Nabila, N. 2011. Pengaruh Pemberian Metanol dan Etanol terhadap Tingkat Kerusakan Sel Hepar Tikus Wistar. Media Medika Muda.

Ohimain, E. I. 2016. Methanol contamination in traditionally fermented alcoholic beverages: the microbial dimension. SpringerPlus, 5(1607): 1-10. DOI: 10.1186/s40064-016-3303-1.

Pratama, M.R., Muhartono. 2019. Dampak mengkonsumsi Alkohol Terhadap Kesehatan Lambung. Majority, 8(2): 254-257.

Polihu, R. M. 2017. Tindak Pidana Penganiayaan Akibat Pengaruh Minuman Beralkohol Menurut KUHP Pasal 351. Lex Crimen, 6(2):114-120.

Purbayanti, Dwi Saputra, N.A.R. 2017. Efek Mengkonsumsi Minuman Beralkohol Terhadap Kadar Trigliserida. Jurnal Surya Medika, 3(1): 1-6. 
Ramdhania, R. N. 2017. Penetapan KadarEtanol Dalam Minuman Keras Oplosan Yang Dijual di Wilayah Jatinegara. Karya Tulis Ilmiah. Jakarta: Poltekkes Kemenkes Jakarta III.

Suwanti, S. 2016. Penetapan Kadar Alkohol Pada Minuman Keras Oplosan di Kecamatan Kranggan Rembang.

Syarifudin. 2013. Penetapan Kadar Etanol dan Metanol pada Minuman Keras Oplosan di Wilayah Kramat Jati Tahun 2013. Karya Tulis Ilmiah. Jakarta: Sekolah Tinggi Ilmu Kesehatan M.H. Thamrin.

Triningrat, A. M. P., Rahayu, N. M. K. and Manuaba, I. P. 2010. Visual Acuity of Methanol Intoxicated Patients Before and After Hemodialysis, Methylprednisolone, and Prednisone Therapy. Jurnal Oftalmologi Indonesia, 7(4): 129132.

Tritama, T.K. 2015. The Consumption of Alcohol and its Effect Towards Health. Majority, 4(8): 7-10.

Yanti, Arisma ,et al. 2019. Optimalisasi Metode Penentuan Kadar Etanol dan Metanol Pada Minuman Keras Oplosan Menggunakan Kromatografi Gas (KG). Indonesian Journal of Chemical Science, 8(1): 55-59.

Yunard, A., Nusanti, S., and Sidik, M. 2016. Methanol Toxic Optic Neuropathy (Characteristic and Evaluation of Therapy). Ophthalmol Ina, 42(1): 38-44. 